\title{
Effect of the organic minerals zinc, manganese, and copper on growth performance and the locomotor system of finishing pigs
}

\author{
Efeito dos minerais orgânicos zinco, manganês e cobre no \\ desempenho produtivo e sistema locomotor de suínos em terminação
}

\author{
Gefferson Almeida da Silva ${ }^{1 *}$; Fernanda Griebeller Fernandez ${ }^{2}$; Ana Paula Backes ${ }^{3}$; \\ Daiane Güllich Donin ${ }^{4}$; Sérgio Rodrigo Fernandes ${ }^{5}$; Alba Kyonara Fireman ${ }^{6}$; Ton \\ $\mathrm{Kramer}^{7}$; Geraldo Camilo Alberton ${ }^{8}$
}

\begin{abstract}
Supplementation with complexed minerals influences the growth performance and the integrity of the locomotor system of animals. The aim of this study was to determine the effect of a complex supplementation of organic minerals (metal-amino acids) consisting of $\mathrm{Zn}(50 \mathrm{ppm}), \mathrm{Mn}(20 \mathrm{ppm})$, and $\mathrm{Cu}(10 \mathrm{ppm})\left(\right.$ Availa ${ }^{\circledR}$ Sow FF Zinpro Corp.) on the growth performance and integrity of the locomotor system in pigs. One hundred and eighty 61 -day-old animals, comprised of females $(n=90)$ and castrated males $(n=90)$, were used in a randomised block factorial design with ten replicates per treatment and sex. The experimental design consisted of two treatments: control (T1) animals without supplementation and treatment (T2) animals that were supplemented with organic minerals $\left(0.75 \mathrm{~g} \mathrm{~kg}^{-1}\right)$. At 112 days of housing (D112), the pigs were subjected to a hoof evaluation, at D115 they were weighed, and at D117, they were slaughtered (178 days of age). After boning, a blind analysis was performed on the medial and lateral condyles of the distal humerus. The supplemented animals (T2) had higher scores for the performance parameters of final weight $(P=0.03)$, weight gain (WG) $(P=0.02)$, and average daily weight gain $(D W G)(P=0.021)$. For $W G, T 2$ showed $3.10 \mathrm{~kg}$ more gain than the control; the increase in females was on average $4.07 \mathrm{~kg}$ and in males $2.45 \mathrm{~kg}$. The prevalence of hoof lesions was $100 \%$ in both groups. The supplementation reduced the incidence of damage to the dew claws $(P=0.02)$ and heel-sole cracks $(P=0.02)$. The incidence of osteochondrosis was $19.13 \%$, with no influence of supplementation. Supplementing pigs with the organic minerals $\mathrm{Zn}, \mathrm{Mn}$, and $\mathrm{Cu}$ during the finishing phase improved the WG, DWG, final weight, and hoof integrity.
\end{abstract}

Key words: Complexed minerals. Osteochondrosis. Swine. weight gain.

\section{Resumo}

A suplementação de minerais complexados influencia o desempenho produtivo e a integridade do aparelho locomotor dos animais. O objetivo deste estudo foi determinar o efeito da suplementação

1 Assistente Técnico, Agroceres PIC, Toledo, PR, Brasil. E-mail: gefferson.a.silva@gmail.com

2 Veterinária Autônoma, Brasil. E-mail: fernandafernandez@gmail.com

3 Discente, Graduação em Medicina Veterinária, Universidade Federal do Paraná, UFPR, Setor Palotina, PR, Brasil. E-mail: anabackes96@gmail.com

4 Prof $^{\mathrm{a}} \mathrm{Dr}^{\mathrm{a}}$, Departamento de Zootecnia,UFPR, Setor Palotina, PR, Brasil. E-mail: dds@ufpr.br

5 Pesquisador, UFPR, Setor Palotina, PR, Brasil. E-mail: srfernandes83@gmail.com

6 Nutricionista, ZINPRO, São Paulo, SP, Brasil. E-mail: AFireman@zinpro.com

7 Gerente de Suínos, Zinpro Animal Nutrition Brasil, Toledo, PR, Brasil. E-mail: tkramer@zinpro.com

8 Prof. Dr., UFPR, Setor Palotina, PR, Brasil. E-mail: alberton@ufpr.br

Autho for correspondence 
de complexo de minerais orgânicos (metal-aminoácidos) composto por Zn (50ppm), Mn (20ppm) e $\mathrm{Cu}(10 \mathrm{ppm})$ (Availa ${ }^{\circledR}$ Sow FF, Zinpro Corp.) no desempenho produtivo e integridade do aparelho locomotor de suínos. Cento e oitenta animais de 61 dias de idade, compostos por fêmeas $(n=90)$ e machos castrados $(\mathrm{n}=90)$, foram usados em um delineamento fatorial em blocos casualizados com dez repetições por tratamento e sexo. O desenho experimental foi composto por dois tratamentos, controle (T1) animais que não receberam suplementação e tratamento (T2) animais que foram suplementados com minerais orgânicos $\left(0,75 \mathrm{~g} \mathrm{~kg}^{-1}\right)$. Aos 112 dias de alojamento (D112) os suínos foram submetidos à avaliação de casco, no D115 foram pesados e no D117 foram abatidos (178 dias de idade). Após a desossa, análise às cegas foi realizada nos côndilos mediais e laterais da porção distal do úmero. Os animais suplementados (T2) apresentaram melhor desempenho para os parâmetros de desempenho de peso final $(\mathrm{P}=0,03)$, ganho de peso (GP) $(\mathrm{P}=0,02)$ e média de ganho de peso diário (GPD) $(\mathrm{P}=0,021)$. Com relação ao GP, T2 apresentou ganho de $3,10 \mathrm{~kg}$ a mais do que o controle; o aumento nas fêmeas foi em média 4,07 $\mathrm{kg}$ e nos machos $2,45 \mathrm{~kg}$. A prevalência de lesões de casco foi de $100 \%$ em ambos os grupos. A suplementação reduziu a incidência de lesões na unha acessória $(\mathrm{P}=0,02)$ e rachadura no talão-sola $(\mathrm{P}=0,02)$. A incidência de osteocondrose foi $19,13 \%$, sem influência da suplementação. Suplementar suínos com minerais orgânicos $\mathrm{Zn}, \mathrm{Mn}$ e Cu durante a fase de terminação melhora o GP, GPD, peso final e integridade do casco.

Palavras-chave: Ganho de peso. Minerais complexados. Osteocondrose. suínos.

\section{Introduction}

The supply of minerals at concentrations required for the proper functioning of animal metabolism is essential for growth, reproduction, good development of cutaneous tissue, maintenance of intestinal integrity, development of the immune system, and protection against cellular damage caused by oxidative stress (NRC, 2012; Richards et al., 2010). However, the supplemented levels frequently exceed those required, which results in high excretion into the environment (Carlson et al., 1999; Hill et al., 2000; Thomaz et al., 2015). Given the impact on the environment, more efficient use of mineral compounds is required. The use of organic sources to replace inorganic compounds is an alternative to reduce the excretion of minerals into the environment (Burkett et al., 2009; Jolliff ; Mahan, 2012; Veum et al., 2004).

The minerals zinc ( $\mathrm{Zn})$, manganese $(\mathrm{Mn})$ and copper $(\mathrm{Cu})$ are often included in diets for pigs in the form of inorganic salts, such as oxides and sulphates. However, the low gastric $\mathrm{pH}$ has a dissociative potential for the minerals, resulting in antagonisms between minerals or between minerals and phytic acid, which might impair absorption and bioavailability (Richards et al., 2010; Sandström, 2001). Organic minerals might, therefore, be more bioavailable than inorganic materials when administered to pigs, chickens and cows (Ballantine et al., 2002; Creech et al., 2004; Leeson; Summers, 2001; Yu et al., 2000).

The higher absorption from the supplementation of complexed minerals has various effects on the animal, including improvements in the integrity of the locomotor system. Locomotor problems reduce herd productivity, leading to the premature culling of animals intended for breeding and growth impairment of those intended for slaughter (Anil et al., 2009; Van Riet et al., 2013). Minerals have a key role in maintaining integrity of the heel, in wound healing, in the speed of epithelial tissue repair, and in cellular integrity (Tomlinson et al., 2004). Their deficiency affects bone size, strength, and growth as well as cartilage structure (McDowell, 2003). Based on the above, the goal of the present study was to evaluate the effect of a metal-amino acid complex $(\mathrm{Zn}, \mathrm{Mn}$, and $\mathrm{Cu}$ ) supplementation on the growth performance and integrity of the locomotor system of pigs in the finishing phase. 


\section{Material and Methods}

The experiment was carried out on a pig fattening farm, located in the city of Toledo, State of Paraná. The experimental protocol was previously approved by the Ethics Committee on the Use of Animals CEUA of the Federal University of Paraná - UFPR Palotina under the number 16/2013.

One hundred and eighty commercial hybrid pigs (Penarlan and Agroceres PIC) comprising 90 females and 90 males (surgically castrated) with initial average weight of $21.6 \pm 1.16 \mathrm{~kg}$ and 61 days until slaughter at 178 days of age were housed in pens with a compact floor $\left(1.09 \mathrm{~m}^{2}\right.$ animal $\left.^{-1}\right)$ equipped with a nipple drinker and a trough feeder. The animals were fed in a controlled management, four times a day until 117 days of age and, from then on, three times a day until slaughter. They were weighed at the beginning of the study and initially blocked by weight and sex. Piglets were weighed at the onset of the experiment and then divided into three groups based on weight: light, medium, and heavy. The experimental design was a randomised block with four treatments and ten replicates. The treatments were established in a $2 \times 2$ factorial arrangement, considering the inclusion or not of complexed minerals with organic components in the diet and the sex of the animals (female and castrated male). The experimental units corresponded to the pens (20), which each contained 9 animals.

Both experimental diets were based on soybean and corn (Table 1). The treatments consisted of a control diet (T1) without the addition of organic minerals and a treatment diet (T2) with the partial substitution of $\mathrm{Zn}, \mathrm{Mn}$, and $\mathrm{Cu}$ by a metal-amino acid complex ${ }^{2}$, included at $0.75 \mathrm{~g} \mathrm{~kg}^{-1}$, which resulted in $50 \mathrm{mg} \mathrm{kg}^{-1} \mathrm{Zn}, 20 \mathrm{mg} \mathrm{kg}^{-1} \mathrm{Mn}$, and $10 \mathrm{mg}$ $\mathrm{kg}^{-1} \mathrm{Cu}$. The inorganic $\mathrm{Zn}, \mathrm{Mn}$, and $\mathrm{Cu}$ levels were reduced to account for the inclusion of the complex as described in Table 2. The metal-amino acid complex used in the present study was produced by the complexation of a metal ( $\mathrm{Zn}, \mathrm{Mn}$, and $\mathrm{Cu}$ ) with a specific amino acid (methionine). From each batch of feed, we collected a $1 \mathrm{~kg}$ sample for analysis with a Microtracer ${ }^{\circledR 3}$ to confirm the presence of the metalamino acid complex in $\mathrm{T} 2$ diet and its absence in the $\mathrm{T} 1$ diet.

The animals were weighed during housing as well as at the end of the experimental period. Data on feed intake per pen were recorded in order to calculate the feed conversion (FC) value and weight was recorded for the calculation of weight gain (WG) and average daily weight gain (DWG).

One week before slaughter, a hoof evaluation was performed in four to five animals per pen, which were appropriately restrained in a trunk for the evaluation. The evaluation of the lesions was performed on the left limbs, as described by Deen et al. (2009).

During the slaughtering process, before evisceration, the earring number was marked on the forelimb with a special pen ${ }^{4}$. After the procedures of slaughter, evisceration, and division of the carcasses, the half-carcasses were weighed to obtain the hot carcass weight. These carcasses were then stored in a cold room at $3{ }^{\circ} \mathrm{C}$ for the establishment of rigor mortis. After $24 \mathrm{~h}$, the half-carcasses were weighed to obtain the cold carcass weight, and then the backfat thickness (BT) values between the $10^{\text {th }}$ and $11^{\text {th }}$ thoracic vertebrae were evaluated with the aid of Ultrafom equipment (UFOM) ${ }^{5}$. The carcass yields were calculated by dividing the weights.

\footnotetext{
2 Availa ${ }^{\circledR}$ Sow FF, Zinpro Corp.

3 Micro-Tracers Inc., San Francisco

4 Meatmark Crayon

5 SFK Ltd., Denmark.
} 


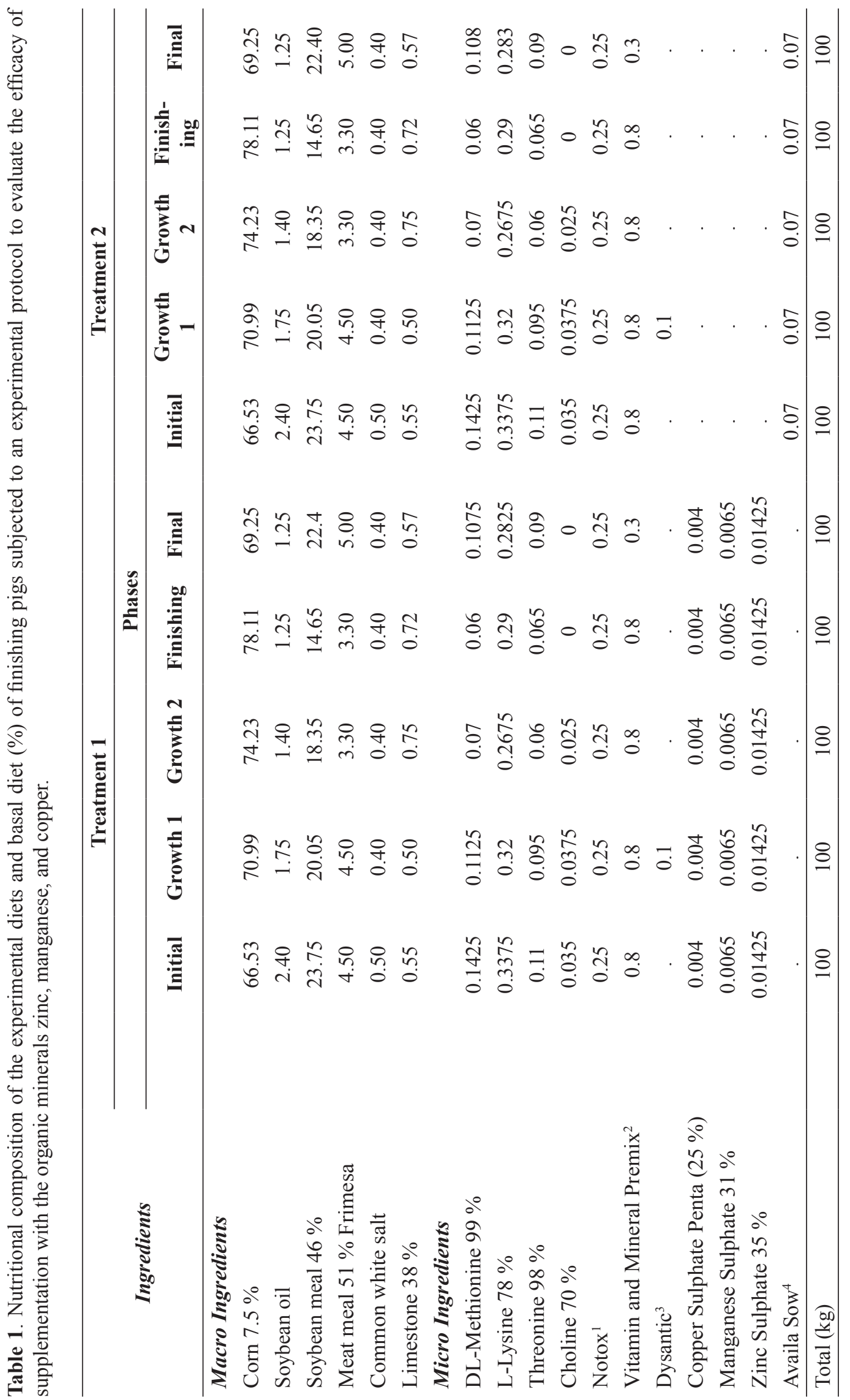




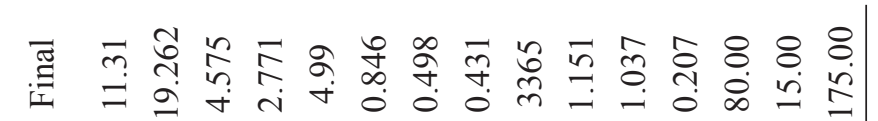

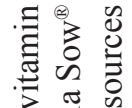

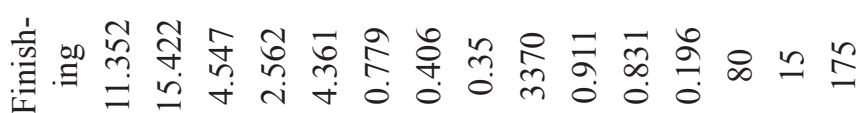

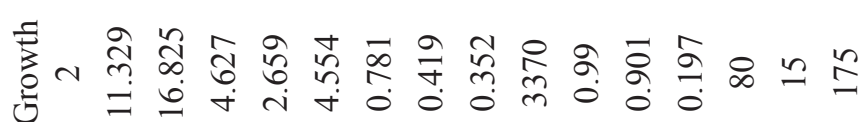

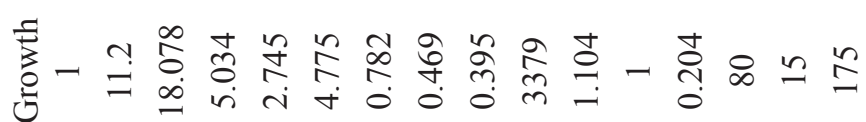

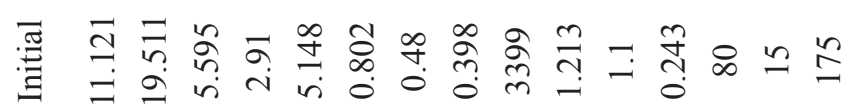

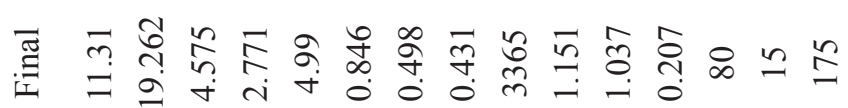

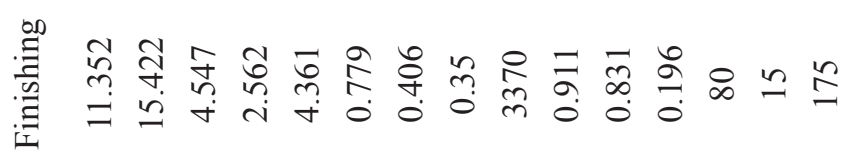

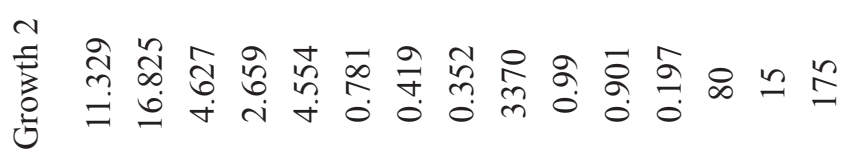

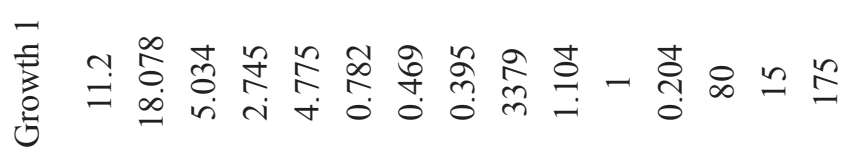

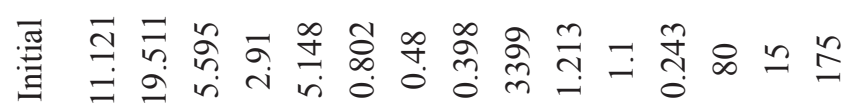

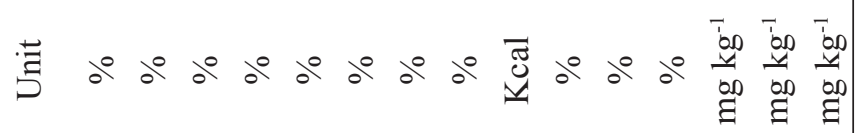

D赵

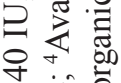

$\stackrel{0}{\circ .0}$.

디릉 ह

쿨 웅

莺官记

D苞

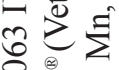

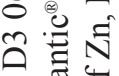

घ

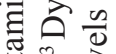

5 is

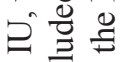

它

远

$\varangle$

芯 荾造

8 :

牙 记

拧

就志署

ฉ ही जै

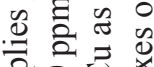

을 记

के 믐

$x$ ิㅡㄹ

킹ㅇㅇ

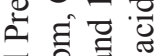

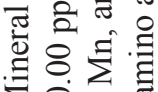

证高

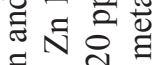

寻䗆

펼 궁

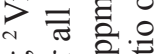

这宁号

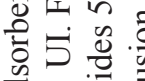

के वे

$\exists$ 연.

文氞

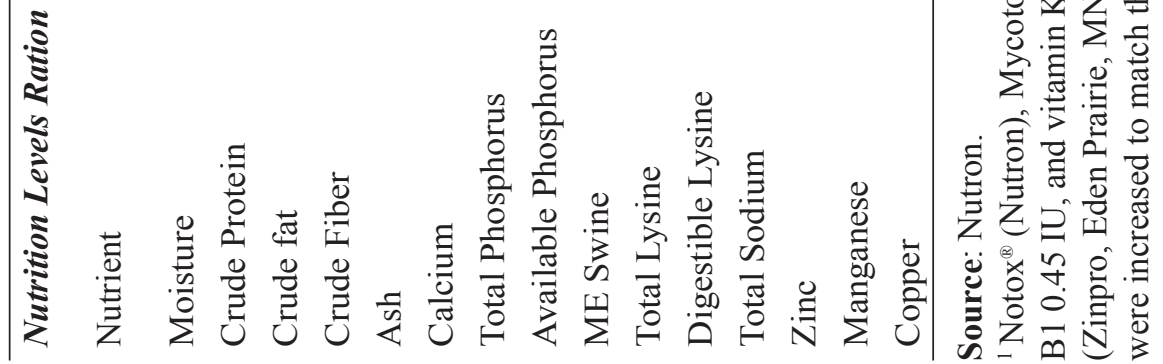


Table 2. Levels of inorganic and organic zinc, manganese, and copper used in experimental diets.

\begin{tabular}{lcccc}
\hline & \multicolumn{2}{c}{ SMI $^{\mathbf{1}}$} & \multicolumn{2}{c}{ SMO $^{2}$} \\
\hline & Inorganic & Organic & Inorganic & Organic \\
\hline $\mathrm{Zn}\left(\mathrm{mg} \mathrm{kg}^{-1}\right)$ & 80 & 0 & 30 & 50 \\
$\mathrm{Mn}\left(\mathrm{mg} \mathrm{kg}^{-1}\right)$ & 15 & 0 & 5 & 10 \\
$\mathrm{Cu}\left(\mathrm{mg} \mathrm{kg}^{-1}\right)$ & 175 & 0 & 155 & 20 \\
\hline
\end{tabular}

${ }^{1}$ SMI: mineral supplement not complexed; ${ }^{2}$ SMO: mineral supplement complexed with organic components.

After cooling, the carcasses were sent to the boning room and the left forelimbs were placed in a tank. After deboning, a blind analysis was performed, with evaluation of the medial and lateral condyles of the distal humerus. Osteochondrosis (OC) lesions were scored on a scale of to five according to Jorgensen (2000), in which: 0: normal; 1: small invagination in the cartilage; 2 : thickened cartilage with prominence to the shape of the bone; 3: thickened cartilage, spaced from the bone, protruding and forming a fold; 4: osteochondrosis dissecans (OCD) thickened cartilage forming flaps.

The performance data were analysed using analysis of variance (PROC GLM) following a randomised complete block design and $2 \times 2$ factorial treatments. The statistical model used was:

$$
\hat{Y}_{i j k}=\mu+B_{i}+M_{j}+S_{k}+M S_{j k}+\varepsilon_{i j k}
$$

where $\hat{\mathrm{Y}}_{\mathrm{ij \textrm {k }}}=$ value of the dependent variable in block $i$, for feed with mineral supplement $j$ and for sex $k ; \mathrm{m}=$ mean value of the dependent variable (constant); $\mathrm{B}_{\mathrm{i}}=$ effect of block $i ; \mathrm{M}_{\mathrm{j}}=$ effect of the feed with mineral supplement $j ; \mathrm{S}_{\mathrm{k}}=$ effect of sex $k ; \mathrm{MS}_{\mathrm{jk}}=$ effect of interaction between mineral supplement type and sex; and $\mathrm{e}_{\mathrm{ijk}}=$ random error. When there was an isolated effect and/or interaction between the factors, the means were compared using an F-test.

The scores of the various types of hoof lesions were used to classify pigs according to the presence or absence of lesions. From this classification, animals were divided into two groups (with and without lesions) that were compared using a Chisquare test (PROC FREQ). The frequency of each hoof lesion type was compared between the diets without and with mineral supplementation complexed with organic components using a MannWhitney U test (PROC NPAR1WAY).

The analyses were run in the Statistical Analysis System, version 9.0 (SAS, 2002), considering the level of significance as $5 \%$.

\section{Results and Discussion}

The animals supplemented with organic minerals showed a better performance (Table 3 ) according to the zootechnical parameters, final weight $(P=0.03)$, WG $(P=0.02)$, and DWG $(P=0.02)$. The T2 group presented $3.10 \mathrm{~kg}$ more gain than the control. In females, the increase was $4.07 \mathrm{~kg}$, and in males that also received this supplementation, the increase was $2.45 \mathrm{~kg}$ compared to the control group. The DWG was on average $0.25 \mathrm{~kg}$ higher for animals supplemented with organic minerals than for control animals, and no interaction with sex $(P>0.05)$ was observed. The feed intake was significantly affected by the factors treatment $(P=0.02)$ and $\operatorname{sex}(P=0.003)$; the males and supplemented animals showed a higher consumption of feed than the females and unsupplemented animals, respectively. Regarding FC, the performance of the females was better than that of the males $(P=0.004)$. 


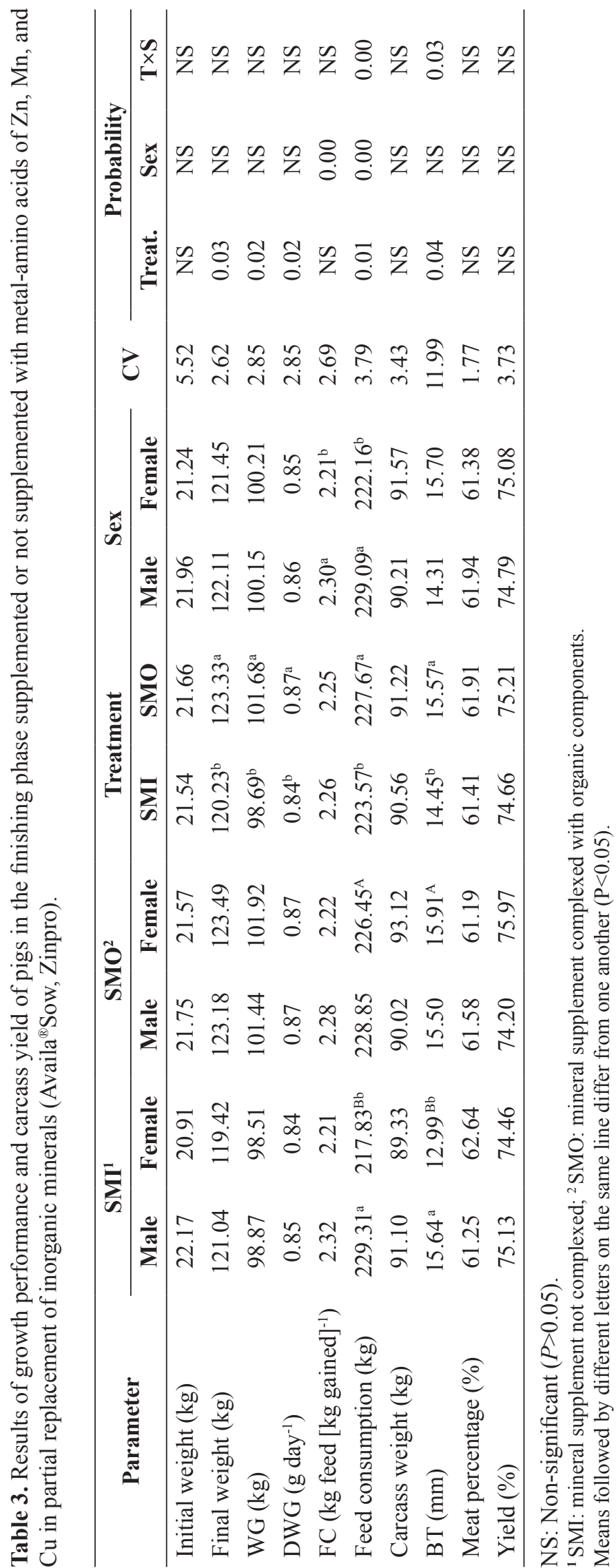


The best WG found in the present study is consistent with the results obtained by Federizzi (2014), who evaluated the effect of supplementation with metal-amino acid complexes ( $\mathrm{Zn}, \mathrm{Mn}$, and $\mathrm{Cu}$ ) in the nursery and finishing phases. The males supplemented in the nursery and finishing phases had a higher WG $(950 \mathrm{~g}$ and $1750 \mathrm{~g})$ than the males of the control group. Rambo et al. (2012) evaluated the effect of organic zinc (Availa $\mathrm{Zn}^{\circledR}$ ) and ractopamine on DWG and carcass traits of growing-finishing pigs (200 animals blocked by initial weight, 81.1 $\mathrm{kg} \pm 0.22 \mathrm{~kg}$ ). In this study, the dietary treatments contained $50 \mathrm{ppm}$ of supplemental zinc $(\mathrm{ZnO})$ or zinc amino acid complex [Availa $\left.{ }^{\circledR} \mathrm{Zn}(\mathrm{AZ})\right]$ from day 0 to 56 and ractopamine (RAC, $7.5 \mathrm{ppm}$ ) during days 35 to 56 of the study. The experimental diets consisted of: 1) control (0.70\% TID Lys) + ZnO; 2) high lysine (1.00\% TID Lys) $+\mathrm{ZnO} ; 3)$ high lysine $+\mathrm{AZ}$; 4) Diet 2 + RAC; or 5) Diet 3 + RAC. The authors found that pigs supplemented with organic Zn (metal-amino acid) had a higher DWG (1.02 kg) than those receiving $\mathrm{ZnO}(0.97 \mathrm{~kg})$. The same result was reported by Muniz et al. (2010), who compared the effects of organic and inorganic micromineral sources on performance, blood parameters, and mineral deposition in tissues and organs of weaned piglets (54 commercial line piglets, weaned at an average age of 24 days with an average weight of $7.35 \pm 0.88 \mathrm{~kg}$ ) in a randomised complete block design with two treatments, nine replicates, and three animals per plot, where the treatments represented the use of feed supplemented with minerals from organic or inorganic sources $(\mathrm{Cu}, \mathrm{Zn}, \mathrm{Fe}, \mathrm{Mn}$, and Se) from 24 to 57 days of age. The authors found a higher DWG in the females and castrated males supplemented with organic minerals during the nursery phase. However, different results have been reported by some authors when evaluating the effect of supplementation with organic minerals on the growth performance of pigs (Case; Carlson, 2002; Creech et al., 2004; Ma et al., 2015).

The better performance with organic mineral complex supplementation can be attributed mainly to the effect of minerals on intestinal integrity (villi) and modulation of the immune system and intestinal microbiota. Zn improves the morphological and functional development of the intestinal mucosa, thus maximising digestion, nutrient absorption, and cell replication, and stimulating the growth of microorganisms and the renewal of enterocytes that cover the intestinal villi ( $\mathrm{Li}$ et al., 2001). $\mathrm{Zn}$ is also involved in numerous metabolic processes and its deficiency results in a reduction in the immune response of the animals (Rink; Kirchner, 2000; Klasing, 2001). Cu is closely related to the body's defence against free radicals, thus preventing oxidative stress (Jondreville et al., 2002). According to McDonald et al. (2002) and Cortinhas (2009), the effect of minerals on the immune system is related to the reduction in immunosuppressive factors, which has the potential to affect the performance and health of the animals.

The higher feed intake (Table 3 ) by males than females was expected. A higher feed intake in castrated males has already been reported in other studies and can be used as an important indicator in growing and finishing phases (Latorre et al., 2003, 2004).

The BT showed a significant effect for treatment $(P=0.02)$, and the animals that received the organic minerals presented higher BT values. For this variable, there was an interaction between treatment and sex. T1 females had a lower BT than males and $\mathrm{T} 2$ females had a higher BT than T1 females (Table 3). There was no significant effect $(P>0.05)$ of mineral supplementation on the variables of carcass weight, lean meat percentage, or carcass yield (Table 3 ).

Rambo et al. (2012) evaluated the traits of animal carcasses and observed that pigs supplemented with organic $\mathrm{Zn}$ (metal-amino acid) and ractopamine had a higher hot carcass weight than animals that received ractopamine and inorganic Zn. However, in a study conducted by Stephenson et al. (2015) that evaluated the carcass traits of animals supplemented 
with organic (metal-amino acid) and inorganic $(\mathrm{ZnO}) \mathrm{Zn}$, no difference was detected $(P>0.05)$ for carcass yield, carcass weight, BT, or loin depth.

The increase in BT in $\mathrm{T} 2$ animals might be due to the high feed consumption of the animals. When the energy consumption increases above that required for maximum lean growth, the fat/ lean tissue deposition ratio increases, as well as the BT and FC. The excessive consumption of food in diets with lower energy contents might influence the intake of protein or other nutrients, contrary to animal requirements, without any benefit to production, and might be detrimental to dietary efficiency (Bertechini, 2006). Recent studies point to the effect of $\mathrm{Zn}$ on the deposition of fat in the carcass. According to Tang and Shay (2001), Zn has some insulin-like effects, such as enhancement of lipogenesis and glucose transport. $\mathrm{Oh}$ and Choi (2004), when assessing the effect of $\mathrm{Zn}$ on lipogenesis in bovine adipocytes, reported that $\mathrm{Zn}$ can cause increased accumulation of lipids in the cytosol, increasing transcription factor expression, and the expression of genes responsible for synthesis of triglycerides.

The incidence of OC in this study was 19.13 $\%$ (Table 4). Although this value is high, it is still much lower than that observed in a study conducted by Federizzi (2014) with fattening pigs (45.15\%). Grevenhof et al. (2012) also observed an incidence of $41 \%$ in fattening pigs. The incidence of $\mathrm{OC}$ in T2 was only $16 \%$, which was $6 \%$ lower than the frequency observed in the T1 group, and lower than that typically observed in the field. The piglets used in this study came from sows supplemented with metal-amino acid complex in gestation, and considering foetal nutrition and piglet nutrition, this might have improved the overall results. According to Frantz et al. (2008), supplementation with $\mathrm{Cu}$ and $\mathrm{Mn}$ can reduce the severity of OC lesions in gilts.

Table 4. Occurrence of osteochondrosis (OC) in finishing animals (\%) supplemented or not supplemented with organic minerals (metal-amino acid $\mathrm{Zn}, \mathrm{Mn}$, and $\mathrm{Cu}$; Availa ${ }^{\circledR}$ Sow, Zinpro) and a comparison of the treatments and sexes.

\begin{tabular}{lccccccccc}
\hline \multirow{2}{*}{ Parameter } & \multirow{2}{*}{$\mathbf{n}$} & \multicolumn{2}{c}{ SMI $^{\mathbf{1}}$} & \multicolumn{2}{c}{ SMO $^{2}$} & \multicolumn{2}{c}{ Treatment } & \multicolumn{2}{c}{ Sex } \\
\cline { 3 - 9 } & & Male & Female & Male & Female & SMI & SMO & Male & Female \\
\hline Without OC * & $132(80.98 \%)$ & 72 & 84 & 85 & 83 & 78 & 84 & 78.5 & 83.5 \\
With OC** & $31(19.01 \%)$ & 28 & 16 & 15 & 17 & 22 & 16 & 21.5 & 16.5 \\
\hline
\end{tabular}

${ }^{1}$ SMI: mineral supplement not complexed; ${ }^{2}$ SMO: mineral supplement complexed with organic components.

When the interaction between the variables OC lesions, OC score, WG, final and initial weight was analysed, no significant effect was detected $(P>0.05)$. These data differ from those presented by Busch and Wachmann (2011) and Alberton et al. (2007), who report a positive correlation of weight gain and lean meat deposition in the carcass with OC lesions.

Rapid growth might impair the formation of bone tissue, mainly due to a failure in cartilage maturation, thus increasing the biomechanical pressure, which might influence the occurrence of $\mathrm{OC}$ in certain age groups during piglet growth (Van Grevenhof et al., 2012). However, according to Ytrehus et al. (2007), the growing cartilages are nourished by channels that undergo a regression pattern which is highly predictable according to age. All animals that were evaluated presented hoof injuries (Table 5); the DWG and final weight, under the conditions evaluated, had no effect on the lesions $(\mathrm{P}>0.05)$. 
Table 5. Incidence of hoof lesions (\%) in finishing pigs supplemented or not supplemented with organic minerals (metal-amino acid $\mathrm{Zn}, \mathrm{Mn}$, and $\mathrm{Cu}$; Availa ${ }^{\circledR} \mathrm{Sow}$, Zinpro).

\begin{tabular}{lccc}
\hline \multirow{2}{*}{ Hoof lesions (\%) } & \multicolumn{2}{c}{ Treatment } & \multirow{2}{*}{$\boldsymbol{P}$} \\
\cline { 2 - 3 } & SMI $^{\mathbf{1}}$ & $\mathbf{S M O}^{\mathbf{2}}$ & \\
\hline General & $100(49 / 49)^{*}$ & $100(48 / 48)$ & 0.16 \\
Horizontal Wall Crack & $24.48(12 / 49)$ & $37.50(18 / 48)$ & 0.50 \\
Vertical Wall Crack & $73.46(36 / 49)$ & $79.16(38 / 48)$ & 0.02 \\
Dew Claws & $42.85(21 / 49)$ & $20.83(10 / 48)$ & 0.94 \\
Heel overgrowth and erosion & $67.34(33 / 49)$ & $66.66(32 / 48)$ & 0.02 \\
Heel-sole crack & $79.59(39 / 49)$ & $58.33(28 / 48)$ & 0.27 \\
Claw & $85.71(42 / 49)$ & $77.08(37 / 48)$ & 0.97 \\
White line & $93.87(46 / 49)$ & $93.75(45 / 48)$ & \\
\hline
\end{tabular}

*Number of animals with lesions/total of animals evaluated.

${ }^{1}$ SMI: mineral supplement not complexed; ${ }^{2}$ SMO: mineral supplement complexed with organic components.

The observation of a high incidence of hoof lesions is in agreement with Mouttotou et al. (1997) and Mouttotou et al. (1999) who found that in the United States, among 3974 pigs evaluated from 17 different farms, $93.8 \%$ of the animals presented some lesion in the hoof. In Sweden, Olsson et al. (2016) observed that among 72 gilts, more than 75 $\%$ of the animals presented lesions in the heel and at the junction between the heel and sole, and $40 \%$ of the animals had lesions on the white line, wall, and sole. In accordance with these studies, Kramer et al. (2013) evaluated 1766 sows from 26 commercial farms and found that $99 \%$ of the matrices had lesions in the locomotor system. Similar results were verified by Seddon et al. (2014) who evaluated 3541 matrices in Canada and found that $94 \%$ of these had lesions.

Evaluating the lesion type alone revealed there was a positive effect on the reduction of dew claw injuries $(P=0.02)$ and heel-sole cracks $(P=0.02)$ among animals receiving mineral supplementation. The results obtained are similar to the findings of Anil et al. (2007) and Anil et al. (2009), who demonstrated that the supplementation of complexed $\mathrm{Zn}, \mathrm{Mn}$, and $\mathrm{Cu}$ reduces the incidence of hoof injuries in pigs. The minerals $\mathrm{Zn}, \mathrm{Mn}$, and $\mathrm{Cu}$ play an important role in the production and maintenance of keratinised tissues and participate in several enzymatic processes (Tomlinson et al., 2004). Inadequate supplementation, both in quantity and in quality, or an alteration in its transport to the keratinocytes, results in the production of low resistance corneal tissues, making the animals susceptible to problems in the hoof and claudication (Tomlinson et al., 2004; Van Riet et al. al., 2013). Lisgara et al. (2016) analysed 518 sows initially examined and monitored for one or two cycles following supplementation with organic trace elements, which partially replaced their inorganic salt forms (organic form of $\mathrm{Zn} 45 \mathrm{ppm}, \mathrm{Cu} 14 \mathrm{ppm}$, and Mn $25 \mathrm{ppm}$ of the total $125 \mathrm{ppm} \mathrm{Zn}, 15 \mathrm{ppm}$ $\mathrm{Cu}$, and $40 \mathrm{ppm} \mathrm{Mn}$, respectively), and found there was a significant reduction in locomotor lesions. Similar results were reported by Souza and Pierozan (2015), who evaluated 500 commercial gitls and sows, housed in individual cages and supplemented with minerals complexed with methionine $(50 \mathrm{ppm}$ Zn-methionine, 20 ppm Mn-methionine, and 10 ppm Cu-methionine) and observed a reduction in the prevalence $(P<0.05)$ of claudication for degrees 1,3 , and 4 for multiparous and degrees $1,2,3$, and 4 for nulliparous females.

Hoof lesions are multifactorial and are mainly associated with nutritional, environmental, and 
management failures (Anil et al., 2007; Muelling, 2009). The result of mineral supplementation will always depend on the other factors involved in the process. In addition, the response to supplementation is dependent on the growth rate of the hooves, which is approximately $6 \mathrm{~mm}$ per month in adult pigs (Van Amstel; Doherty, 2010) and $10 \mathrm{~mm}$ in young pigs (Johnston; Penny, 1989). Knowing that the adult animal hull in ideal conditions is 35 to $54 \mathrm{~mm}$ (Amstel et al., 2009), and knowing the speed of growth of this, we can infer that at least five months are required for the total replacement of the corneal tissue that constitutes the hoof. The experimental period was four months, therefore, there was not enough time for the total replacement of the hoof. Thus, mineral supplementation over a longer time course might be an alternative to guarantee improvements in the integrity of the hoof under adequate environmental conditions.

Mineral supplementation does not have the potential to solve all locomotor problems, considering that it is a multifactorial disease in which the environment makes a great contribution to the appearance of the lesions. The environment impacts on the integrity of the hoof due to softening as a result of contact with water (Borderas et al., 2004), injuries due to bad floor conditions, and low resistance and elasticity due to ammonia in faeces (Gregory et al., 2006; Higuchi et al., 2009), which culminate in the appearance of lesions that will be the gateway for bacterial infections generating pain and discomfort caused by inflammation (Van Amstel; Doherty, 2010).

Supplementation of organic $\mathrm{Zn}, \mathrm{Mn}$, and $\mathrm{Cu}$ (metal-amino acid) in partial replacement during the finishing phase improves WG, DWG, and final weight. It impacts positively on FC for females and reduces the incidence of locomotor lesions in the dew claw and heel-sole. This is in agreement with the goal of the modern pig production system, due to the possibility of reduce the level of mineral discharged in the environment when using organic mineral and promote benefits to animal's welfare while reduces the incidence of disease.

\section{Conclusions}

Pigs in finishing phase fed with diets contending metal-amino acid complex of $\mathrm{Zn}, \mathrm{Mn}$, and $\mathrm{Cu}$ had better growth performance and reduced incidence of hoof injuries.

\section{Acknowledgements}

Thanks to Zinpro Corp. and CAPES for their financial support to conduce this study.

\section{References}

ALBERTON, G. C.; SOBESTIANSKY, Y.; BARCELLOS, D.; MORES, N.; DONIN, D. G.; OLIVEIRA, S. J. Doenças do aparelho locomotor. In: SOBESTIANSKY, J.; BARCELLOS, D. (Ed.). Doenças dos suínos. 2. ed. Goiânia: Cânone Editorial, 2007. p. 509-550.

AMSTEL, S.V.; WARD, T.; WINDERS, M.; WILSON, M.; BOONE, T. Claw size in cull sows, quantification of a potential factor in lameness and culling. In: ANNUAL MEETING OF THE AMERICAN ASSOCIATION OF SWINE VETERINARIANS, 40., 2009. Proceedings of the American Association of Swine Veterinarians Annual Meeting. 2009. p. 375-376.

ANIL, S. S.; ANIL, L.; DEEN, J.; BAIDOO, S. K.; WALKER, R. D. Factors associated with claw lesions in gestating sows. Journal of Swine Health and Production, v. 15, n. 2 , p. $78-83,2007$.

ANIL, S. S.; DEEN, J.; ANIL, L.; BAIDOO, S. K.; WILSON, M. E.; WARD, T. L. Evaluation of the supplementation of complexed trace minerals on the number of claw lesions in breeding sows. Manipulating Pig Production XII, Australasian Pig Science Association, v. 108, p. 22-25, 2009.

BALLANTINE, H. T.; SOCHA, M. T.; TOMLINSON, D. J.; JOHNSON, A. B.; FIELDING, A. S.; SHEARER, J. K.; VAN AMSTEL, S. R. Effect of feeding complexed zinc, manganese, copper and cobalt to late gestation and lactating dairy cows on claw integrity, reproduction and lactation performance. The Professional Animal Scientist, v. 18, n. 3, p. 211-218, 2002. DOI: 10.15232/ S1080-7446(15)31524-2

BERTECHINI, A. G. Nutrição de monogástricos. Lavras: Universidade Federal de Lavras, 2006. 301 p.

BORDERAS, T. F.; PAWLUCZUK, B.; DE PASSILLE, A. M.; RUSHEN, J. Claw hardness of dairy cows: 
relationship to water content and claw lesions. Journal of Dairy Science, v. 87, n. 7, p. 2085-2093, 2004. DOI: 10.3168/jds.S0022-0302(04)70026-0

BURKETT, J. L.; STALDER, K. J.; POWERS, W. J.; BREGENDAHL, K.; PIERCE, J. L.; BAAS, T. J.; BAILEY, T.; SHAFER, B. L. Effect of inorganic and organic trace mineral supplementation on the performance, carcass characteristics, and fecal mineral excretion of phase-fed, grow-finish swine. Asian Australasian Journal of Animal Science, v. 22, n. 9, p. 1279, 2009. DOI: 10.5713/ajas.2009.70091

BUSCH, M. E.; WACHMANN, H. Osteochondrosis of the elbow joint in finishing pigs from three herds: associations among different types of joint changes and between osteochondrosis and growth rate. The Veterinary Journal, v. 188 , n. 2, p. 197-203, 2011. DOI: $10.1016 /$ j. tvj1.2010.03.021

CARLSON, M. S.; HILL, G. M.; LINK, J. E. Early- and traditionally weaned nursery pigs benefit from phasefeeding pharmacological concentrations of zinc oxide: effect on metallothionein and mineral concentrations. Journal of Animal Science, v. 77, n. 5, p. 1199-1207, 1999. DOI: $10.2527 / 1999.7751199 x$

CASE, C. L.; CARLSON, M. P. Effect of feeding organic and inorganic sources of additional zinc on growth performance and zinc balance in nursery pigs. Journal of Animal Science, v. 80, n. 7, p. 1917-1924, 2002. DOI: $10.2527 / 2002.8071917 \mathrm{x}$

CORTINHAS, C. S. Fornecimento de zinco, cobre e selênio orgânicos para vacas leiteiras e efeitos sobre a qualidade e saúde da glândula mamária. 2009. Dissertação (Mestrado em Nutrição e Produção Animal) - Universidade de São Paulo, Pirassununga.

CREECH, B. L.; SPEARS, J. W.; FLOWERS, W. L.; HILL, G. M.; LLOYD, K. E.; ARMSTRONG, T. A.; ENGLE, T. E. Effect of dietary trace mineral supplementation and source (inorganic vs. chelated) on performance, mineral status, and fecal mineral excretion in pigs from weaning through finishing. Journal of Animal Science, v. 82, n. 7, p. $2140-2147,2004$. DOI: $10.2527 / 2004.8272140 \mathrm{x}$

DEEN, J.; SCHUTTERT, M.; VAN AMSTEL, S.; OSSENT, P.; VAN BARNEVELD, R. Feet first from zinpro: lesion scoring guide. Zinpro Corporation, Eden Prairie, MN, USA.

FEDERIZZI, K. C. Efeito da suplementação de complexo metal-aminoácido de zinco, manganês e cobre sobre $o$ desempenho zootécnico e integridade do aparelho locomotor de suínos. 2014. Dissertação (Mestrado Ciência Animal) - Universidade Federal do Paraná, Palotina.
FRANTZ, N. Z.; NELSSEN, J. L.; ANDREWS, G. A.; TOKACH, M. D.; GOODBAND, R. D.; DEROUCHEY, J. M.; DRITZ, S. S. Effect of dietary nutrients on osteochondrosis lesions and cartilage properties in pigs. American Journal of Veterinary Research, v. 69, n. 5, p. 617-624, 2008. DOI: 10.2460/ajvr.69.5.617

GREGORY, N.; CRAGGS, L.; HOBSON, N.; KROGH, C. Softening of cattle hoof soles and swelling of heel horn by environmental agents. Food and Chemical Toxicology, v. 44, n. 8, p. 1223-1227, 2006. DOI: 10.1016/j.fct.2006.01.018

GREVENHOF, E. M.; HEUVEN. H. C. M.; WEEREN. P. R.; BIJMA, P. The relationship between growth and osteochondrosis in specific joints in pigs. Livestock Science, v. 143, n. 1, p. 85-90, 2012. DOI: $10.1016 / j$. livsci.2011.09.002

HIGUCHI, H.; KURUMADO, H.; MORI, M.; DEGAWA, A.; FUJISAWA, H.; KUWANO, A.; NAGAHATA, H. Effects of ammonia and hydrogen sulfide on physical and biochemical properties of the claw horn of Holstein cows. The Canadian Journal of Veterinary Research, v. 73, n. 1, p. 15, 2009. PMID: 19337390

HILL, G. M.; CROMWELL, G. L.; CRENSHAW, T. D.; DOVE, C. R.; EWAN, R. C.; KNABE, D. A.; LEWIS, A. J.; LIBAL, G. W.; MAHAN, D. C.; SHURSON, G. C.; SOUTHERN, L. L.; VEUM, T. L. Growth promotion effects and plasma changes from feeding high dietary concentrations of zinc and copper to weanling pigs (regional study). Journal of Animal Science, v. 78, n. 4, p. 1010-1016, 2000. DOI: 10.2527/2000.7841010x

JOHNSTON, A. M.; PENNY, R. H. Rate of claw horn growth and wear in biotinsupplemented and nonsupplemented pigs. Veterinary Record, v. 125, n. 6, p. 130-132, 1989. DOI: 10.1136/vr.125.6.130

JOLLIFF, J. S.; MAHAN D. C. Effect of dietary inulin and phytase on mineral digestibility and tissue retention in weanling and growing swine. Journal of Animal Science, v. 90, n. 9, p. 3012-3022, 2012. DOI 10.2527/ jas.2011-4424

JONDREVILLE, C.; PREVY, P. S.; JAFFREZIC, A. Le cuivre dans l'alimentation du porc: oligo-élément essentiel, facteur de croissance et risque potentiel pour l'homme et l'environnement. Productions Animales Paris Institut National de la Recherche Agronomique, v. 15, n. 4, p. 247-266, 2002.

JORGENSEN, B. Osteochondrosis/osteoarthrosis and claw disorders in sows, associated with leg weakness. Acta Veterinaria Scandinavica, v. 41, n. 2, p. 123-138, 2000. 
KLASING, K. C. Protecting animal health and wellbeing: nutrition and immune function. Scientific Advances in animal nutrition: promise for the new century: Proceedings of a Symposium. Natational Academies Press, Washington, 2001.

KRAMER, T.; SOUZA, T. C. G. D.; TEIXEIRA, A. P.; ALBERTON, G. C. Prevalência de lesões de casco e porcas da região Sul e Sudeste do Brasil. In: CONGRESSO ABRAVES, 16., 2013, Cuiabá. Anais ... Cuiabá; 2013.

LATORRE, M. A.; LÁZARO, R.; GRACIA, M. I.; NIETO, M.; MATEOS G. G. Effect of sex and terminal sire genotype on performance, carcass characteristics, and meat quality of pigs slaughtered at $117 \mathrm{~kg}$ body weight. Meat Science, v. 65, n. 4, p. 1369-1377, 2003. DOI: 10.1016/S0309-1740(03)00059-7

LATORRE, M. A.; LÁZARO, R.; VALENCIA, D. G.; MEDEL, P.; MATEOS G. G. The effects of gender and slaughter weight on the growth performance, carcass traits, and meat quality characteristics of heavy pigs. Journal of Animal Science, v. 82, n. 2, p. 526-533, 2004. DOI: $10.1093 /$ ansci/82.2.526

LEESON, S.; SUMMERS J. D. Scott's nutrition of the chicken. $4^{\text {th }}$ ed. University Books, Guelph, 2001.

LI, B. T.; VAN KESSEL, A. G.; CAINE, W. R.; HUANG, S. X.; KIRKWOOD, R. N. Small intestinal morphology and bacterial populations in ileal digesta and feces of newly weaned pigs receiving a high dietary level of zinc oxide. Canadian Journal of Animal Science, v. 81, n. 4, p. 511-516, 2001. DOI: 10.4141/A01-043

LISGARA, M.; SKAMPARDONIS, V.; LEONTIDES, L. Effect of diet supplementation with chelated zinc, copper and manganese on hoof lesions of loose housed sows. Porcine Health Management, v. 2, n. 1, p. 6, 2016. DOI: $10.1186 / \mathrm{s} 40813-016-0025-2$

MA, Y. L.; LINDEMANN, M. D.; CROMWELL, G. L.; COX, R. B. Evaluation of trace mineral source and preharvest deletion of trace minerals from finishing diets for pigs on growth performance, carcass characteristics, and pork quality. Journal of Animal Science, v. 90, n. 11, p. $3833-3841$, 2012. DOI: $10.2527 /$ jas.2011-4535

MCDONALD, P.; EDWARDS, R. A.; GREENHALGH, J. F. D.; MORGAN, C. A. Animal nutrition. $6^{\text {th }}$ ed. New York: Scientific and Tech John Willey \& Sons, 2002.

MCDOWELL, L. R. Copper and molybdenum. In: MCDOWELL, L. R. Minerals in animal and human nutrition. Amsterdam: Elsevier, 2003. p. 235-270.

MOUTTOTOU, N.; HATCHELL, F. M.; GREEN, L. E. Foot lesions in finishing pigs and their associations with the type of floor. The Veterinary Record, v. 144, n. 23, p. 629-632, 1999. DOI: 10.1136/vr.144.23.629
MOUTTOTOU, N.; HATCHELL, F. M.; LUNDERVOLD, M.; GREEN, L. E. Prevalence and distribution of foot lesions in finishing pigs in south-west England. The Veterinary Record, v. 141, n. 5, p. 115-120, 1997. DOI: $10.1136 /$ vr.141.5.115

MUELLING, C. K. W. Nutritional influences on horn quality and hoof health. Western Canadian Dairy Seminar, v. 21, p. 283-291, 2009.

MUNIZ, M. H. B.; BERTO, D. A.; AUGUSTO, R. M. N.; NETO, M. A. T.; WECHSLER, F. S.; TIERZO, V. L.; HAUPTLI. Fontes de minerais orgânicos e inorgânicos para leitões desmamados. Ciência Rural, Santa Maria, v. 40, n, 10, p. 2163-2168, 2010.

NATIONAL RESEARCH COUNCIL- NRC. Nutrient requirements of swine. $11^{\text {th }}$ ed. Washington: National Academies Press, 2012.

$\mathrm{OH}$, S. C.; CHOI, B. C. Effects of zinc on lipogenesis of bovine intramuscular adipocytes. Asian Australasian Journal of Animal Science, v. 17, n. 10, p. 1378-1382, 2004. DOI: 10.5713 /ajas.2004.1378

OLSSON, A. C.; SVENDSEN, J.; BOTERMANS, J.; BERGSTEN, C. An experimental model for studying claw lesions in growing female pigs. Livestock Science, v. 184, p. 58-63, 2016. DOI: 10.1016/j.livsci.2015.12.005

RAMBO, Z.; SCHINCKEL, A.; WILSON, M. E.; WARD, T.; RICHERT, B. Effect of supplemental zinc source and ractopamine on grow-finish pig growth performance and carcass characteristics. Journal Animal Science, v. 90, p. 71, 2012. Supplement 2.

RICHARDS, J. D., ZHAO, J.; HARRELL, J.; ATWELL, C. A.; DIBNER, J.J. Trace mineral nutrition in poultry and swine. Asian Australasian Journal of Animal Sciences, v. 23, n. 11, p. 1527-1534, 2010. DOI: 10.5713/ajas.2010.r.07

RINK, L.; KIRCHNER, H. Zinc-altered immune function and cytokine production. Journal of Nutrition, v. 130, n. 5, p. 1407-1411, 2000. DOI:10.1093/jn/130.5.1407S

SANDSTRÖM, B. Micronutrient interactions: effects on absorption and bioavailability. British Journal of Nutrition, v. 85 , n. 2, p. $181-185$, 2001. DOI: 10.1049 / BJN2000312

STATISTICAL ANALYSIS SYSTEM INSTITUTE SAS INSTITUTE INC. System for Microsoft Windows, Release 9.2. Cary: 2002. CD-ROM.

SEDDON, Y.; RIOJA-LANG, F.; EITHER, S.; BROW, $\mathrm{J}$. Evaluation of lameness prevalence in large Canadian sow herd and an intervention to reduce prevalence. In: INTERNATIONAL PIG VETERINARY SOCIETY (IPVS) CONGRESS, 23., 2014, Cancun. Proceedings... Cancun, 2014. 
SOUZA, T. C. G. D.; PIEROZAN, E. A. Complexed minerals on prevention and treatment of locomotor problems in sows. Ciência Animal, Santa Maria v. 13, p. 159-165, 2015.

STEPHENSON, E. W.; WOODWORTH, J. C.; TOKACH, M. D.; DEROUCHEY, J. M.; GOODBAND, R. D.; DRITZ, S. S. The effects of increasing organic or inorganic zinc on growth performance and carcass characteristics of finishing pigs. Kansas Agricultural Experiment Station Research Reports. Swine Day Article, v. 1, n. 7 , p. 28,2015 . DOI: $10.4148 / 2378-5977.1133$

TANG, X.; SHAY, N. F. Zinc has an insulin-like effect on glucose transport mediated by phosphoinositol-3kinase and Akt in 3T3-L1 fibroblasts and adipocytes. The Journal of Nutrition, v. 131, n. 5, p. 1414-1420, 2001. DOI:10.1093/jn/131.5.1414

THOMAZ, M. C.; WATANABE, P. H.; PASCOAL, L. A. F.; ASSIS, M. M.; RUIZ, U. S.; AMORIM, A. B.; SILVA, S. V.; ALMEIDA, V. V.; MELO, G. M. P.; ROBLESHUAYNATE, R. A. Inorganic and organic trace mineral supplementation in weanling pig diets. Anais da Academia Brasileira de Ciências, Rio de Janeiro, v. 87 , n. 2, p. 1071-1081, 2015. DOI: 10.1590/00013765201520140154

TOMLINSON, D. J.; MULLING, C. H.; FAKLER, T. M. Formation of keratins in the bovine claw: roles of hormones, minerals, and vitamins in functional claw integrity. Journal of Dairy Science, v. 87, n. 4, p. 797809, 2004. DOI: 10.3168/jds.S0022-0302(04)73223-3
VAN AMSTEL, S.; DOHERTY, T. Claw horn growth and wear rates, toe length, and claw size in commercial pigs: a pilot study. Journal of Swine Health and Production, v. 18, n. 5, p. 239-243, 2010.

VAN GREVENHOF, E. M.; HEUVEN, H. C. M.; VAN WEEREN, P. R.; BIJMA, P. The relationship between growth and osteochondrosis in specific joints in pigs. Livestock Science, v. 143, n. 1, p. 85-90, 2012. DOI: 10.1016/j.livsci.2011.09.002

VAN RIET, M. M. J.; MILLET, S.; ALUWÉ, M.; JANSSENS, G. P. J. Impact of nutrition on lameness and claw health in sows. Livestock Science, v. 156, n. 1-3, p. 24-35, 2013. DOI: 10.1016/j.livsci.2013.06.005

VEUM, T.L.; CARLSON, M. S.; WU,C.W.; BOLLIGER, D. W.; ELLERSIECK, M. R. Copper proteinate in weanling pig diets for enhancing growth performance and reducing fecal copper excretion compared with copper sulfate. Journal of Animal Science, v. 82, n. 4, p. 1062-1070, 2004. DOI: 10.1093/ansci/82.4.1062

YTREHUS, B.; CARLSON, C. S.; EKMAN, S. Etiology and pathogenesis of osteochondrosis. Veterinary Pathology, v. 44, n. 4, p. 429-448, 2007. DOI: 10.1354/ vp.44-4-429

YU, B.; HUANG, W.; CHIOU, P. W. Bioavailability of iron from amino acid complex in weanling pigs. Animal Feed Science and Technology, v. 86, n. 1-2, p. 39-52, 2000. DOI: 10.1016/S0377-8401(00)00154-1 